\title{
From Environmental Sociology to Ecosociologies
}

\author{
GRAHAM WOODGATE
}

\author{
In Chone, E, A Hajek and P Hamman (2016/forthcoming) Rethinking Nature, Challenging \\ Disciplinary Boundaries, London and New York: Routledge.
}

\begin{abstract}
Sociological engagement with the material bases of social life has a long, but intermittent and sometimes overlooked, genealogy. The emergence of the modern environmental movement in the 1960s and events like the first 'Earth Day' in 1970, followed soon after by the postulation of material 'limits to growth', whilst generating significant sociological interest, also revealed the inadequacy of then-dominant forms of sociological enquiry. Entrenched anthropocentrism, born from engagement with the 'exuberant expansion' of Western civilisation in a context of abundant natural resources, limited sociology's ability to shed light on the societal relevance of changing ecological circumstances. At a time when heavyweight US sociologists such as Talcot Parsons, were still focusing their attention on functional societal evolution and Daniel Bell was deriding the concerns of the ecology movement as 'apocalyptic hysteria', Catton and Dunlap $(1978,1980)$ called for sociology to reject what they termed the 'human exceptionalist paradigm' (HEP), which they associated with the dominant US sociological canon and adopt a 'new ecological paradigm' (NEP) for a 'postexuberant' sociology.
\end{abstract}

The following pages will sketch out some key contributions to the construction of a new ecological paradigm of what is now widely referred to as 'environmental sociology'. These include not only recent conceptual developments and theories of environmental degradation and ecological reform, but also re-appraisals of the ecological dimensions of the work of sociology's founding scholars ${ }^{1}$. The chapter will also highlight important cleavages within environmental sociology and the enduring controversies that these have produced. It will close by supporting the idea that critical realist philosophy might provide a framework for the integration of a variety of ecosociological approaches that acknowledge the importance of both social and material influences in the character and dynamics of socioenvironmental relations.

\section{Theories of environmental degradation and ecological reform}

In their seminal paper 'Environmental Sociology: A New Paradigm', Catton and Dunlap criticised contemporary sociology as deeply anthropocentric and incapable of illuminating the societal relevance of environmental change, proposing their NEP as a corrective (see Table 1). The central focus of environmental sociology, they declared, should be 'interaction between the environment and society' (Catton \& Dunlap, 1978: 44, emphasis in original), including the impacts of environment on society as well as those of society on the environment. These interactions imply ecological relations (flows of energy and materials) and social relations (of production and consumption), both of which occur across space and time. Emerging in the context of growing societal concern about resource scarcity and ecological decline, research and scholarship initially sought to explain the social causes of these phenomena.

Ecological explanations were informed by human ecology, the basic tenets of which are reflected in the assumptions of the NEP. According to Catton and Dunlap (1980: 34), environmental degradation is produced by the failure of the dominant western world view to 
recognise and acknowledge the ecological embeddedness and interdependence of society, while the HEP of conventional sociology made it blind to the social and political dimensions of environmental change. For Catton and Dunlap, the solution to continuing environmental decline resided in the spread of values associated with the NEP among mass publics and the institutionalisation of ecological behavioural norms. Research in this branch of environmental sociology includes large scale surveys to measure public endorsement of the NEP (Dunlap et al., 2000) and statistical analyses of interrelationships between variables in the ecological complex such as population, affluence, social organisation and technology. Of particular note is Dietz and Rosa's (1994) stochastic reformulation of the simple I = P.A.T. ${ }^{2}$ ecological model of environmental impact, which has allowed them and their colleagues to generate more sociologically nuanced, comparative analyses of societies' environmental impacts. As we shall see later, their STIRPAT ${ }^{3}$ model has also been employed to test empirical support for environmental social theory.

\begin{tabular}{|l|l|}
\hline Human Exceptionalist Paradigm (HEP) & New Ecological Paradigm (NEP) \\
\hline Our culture makes us exceptional. & Humans are one species among many. \\
\hline $\begin{array}{l}\text { Past experience of 'abundance' makes } \\
\text { 'scarcity' difficult to comprehend. }\end{array}$ & $\begin{array}{l}\text { The world is finite, so there are potent } \\
\text { physical and biological limits constraining } \\
\text { economic growth and social progress. }\end{array}$ \\
\hline $\begin{array}{l}\text { Focus on 'social environment' and functional } \\
\text { evolution of society led to neglect of material } \\
\text { circumstances/ecological embeddedness. }\end{array}$ & $\begin{array}{l}\text { Intricate linkages of cause, effect, and } \\
\text { feedback in the web of nature produce many } \\
\text { unintended consequences from purposive } \\
\text { human action. }\end{array}$ \\
\hline $\begin{array}{l}\text { Cultural accumulation means that progress can } \\
\text { continue without limit, making all social } \\
\text { problems ultimately soluble: society is exempt } \\
\text { from 'natural laws'. }\end{array}$ & $\begin{array}{l}\text { While human inventiveness may appear to } \\
\text { extend global carrying capacity, our } \\
\text { exceptional status does not exempt us from the } \\
\text { laws of nature. }\end{array}$ \\
\hline
\end{tabular}

Table 1. Environmental sociology's paradigm shift.

Sources: Constructed from Catton and Dunlap (Catton \& Dunlap, 1978, 1980).

In contrast, early work by Schnaiberg $(1975,1980)$, turned to political economy and dialectical reasoning to explore the role of capitalist relations and modern state institutions in the genesis of environmental degradation. His 1975 paper, 'Social syntheses of the societalenvironmental dialectic', posited that economic growth requires increased environmental extraction, leading to ecological disruption and resource depletion, which threaten further economic expansion. He identified three possible syntheses for the dialectic: the 'economic synthesis' - involving minimal or no response to degradation but the acceleration of economic expansion; the planned scarcity synthesis - where science and regulatory policy address only the most serious resource constraints and ecological problems; and the ecological synthesis - where ecological disruption is subject to detailed analysis and economic growth is restricted, with the aim of moving towards a steady state economy. The distributional effects (regressive, neutral or progressive) of policies associated with each synthesis would impact social stratification and prompt political mobilisation.

Schnaiberg further developed this approach in his 1980 book The Environment, where he introduced the concept of 'the treadmill of production' into his explanatory model of environmental decline. The concept is closely associated with the growing ecological crisis, because accumulation requires the extraction of ever more resources and produces increasing levels of pollution. At the same time, as suggested by the societal-environmental dialectic, 
declining resource availability and increasing ecological degradation engender both political mobilisation and state regulation.

In the 1970s and 1980s, efforts to incorporate nature into the explanatory framework of political economy and to address the absence of 'power' in human and cultural ecology resulted in the emergence of 'political ecology' as an approach to struggles over the environment in less industrialised counties. At the same, the birth of the modern environmental movement in the advanced capitalist countries was accompanied by the formation of green political parties and the emergence of what has been termed the 'environmental state' (Mol \& Buttel, 2002), as governments established environment ministries and enacted environmental legislation aimed at addressing the most significant ecological problems associated with industrial development. Since the1980s, however, neoliberal demands for 'smaller states' and deregulation aimed at stimulating economic growth, have coincided with the establishment of political programmes of 'ecological modernisation' at national, regional and global scales. This trend was accompanied by the development of ecological modernisation as a social theory (EMT) of environmental reform (Mol, 1997). In contrast to treadmill theory and political ecology, EMT emphasises the importance of market dynamics in ecological reform, identifying green entrepreneurs and environmentally aware consumers as social carriers of ecological restructuring. Similarly, rather than viewing science and technology as perpetrators of ecological and social disruption, EMT casts them as key institutions of ecological reform. In line with neo-liberal thinking, EMT maintains that state interventions in the economy should be limited and focused on promoting sustainability through decentralised, participatory policy making, thus engaging environmental social movements as they transition from critical commentators on development to critical participants in ecological reform (Mol, 1997: 140-142). Thus, in stark contrast to treadmill theory, ecological modernisation focuses on social processes that delink economic growth from its environmental impacts, through gains in production efficiency and demands for more environmentally-friendly goods and services from ecologically aware consumers, facilitated by the environmental state.

This shift in focus also reflects a notable, although not rigid, distinction between North American and European approaches and subject matter ${ }^{4}$. US scholars have tended to focus on the social causes and consequences of environmental degradation and embraced what Schnaiberg (1980) termed 'impact science' as a source of empirical evidence of ecological decline. Their European colleagues, meanwhile, have been more inclined to engage with social responses to perceived environmental change and institutional processes of environmental reform, often maintaining a strong commitment to conventional sociological approaches and integrating insights from emergent sociological framings. In particular, the postmodern turn in European sociology took up a critical position vis-à-vis environmental knowledge claims (Macnaughten \& Urry, 1995) and argued vociferously against the sociologically naïve incorporation of environmental science in public policy (Shackley \& Wynne, 1996). There followed intense and sometimes heated debate between realists and constructivists 5 .

In a 2003 paper, York, Rosa and Dietz employed their realist, human ecology-inspired STIRPAT model to interrogate the empirical validity of the assumptions underlying human ecology, political economy, and EMT theoretical constructs. Using ecological footprint data to operationalise the dependent variable 'environmental impact', their analysis sustained the claims of human ecology, as well as some of those suggested by political economy models such as the treadmill of production. However, the analysis offered no support for the delinking of economic growth from environment impact (the Environmental Kuznets Curve), found a positive link between urbanisation and environmental decline, and revealed no clear 
mitigation effects of policy, political rights, civil liberties, service sector development or market liberalisation on environmental impact, thus completely undermining EMT. More recently, Foster (2012) has launched a withering attack on EMT, which he brands the "new human exemptionalism', for its lack of attention to the material outcome of political programmes of ecological modernisation. Mol and colleagues have responded to this critique by analysing differences between the North American and European traditions in terms of the contexts in which they developed and the distinct cultures of environmental sociology that these have spawned. North American environmental sociology has focused predominantly on resource scarcity and environmental degradation and developed in response to the perceived inadequacies of classical sociological theory. As a result, US environmental sociologists have re-examined classical theory and developed a view of the environment 'as partly constituted by biophysical realities independent of social practices'. In contrast, European environmental sociology has engaged more with contemporary sociological theory and focused on processes of environmental reform, taking up the position that while the biophysical world is undeniably real, it is 'always and only actualised through social practices and interpretative processes’ (Lidskog et al., 2015: 351).

For Lidskog et al. (2015) the differences between US and European environmental sociologies have become more entrenched in recent years, although in some ways the gulf between realists and constructivists has narrowed. Realists have deconstructed and debunked climate change denial (McCright \& Dunlap, 2010) and generally taken up a more critical position with regard to environmental knowledges. Constructivists, on the other hand, have demonstrated convincingly that sophisticated computer models are just as likely to underestimate as to overestimate the climatic impacts of global warming, clearly accepting climate change as empirically verifiable, even if its complex causes, feedback loops and precise dimensions are only relevant in terms of the knowledge claims and policy prescriptions that are made in relation to them. Constructivists have also criticised attempts to translate science directly into public policy (Wynne, 2010), set within the disempowering neo-liberal framing of the green consumer (Redclift \& Woodgate, 2014). Such critiques arguably re-enforce rather than undermine ecological reform as an intellectual mission. Nonetheless, Dunlap (2010: 28) is in agreement with Lidskog and colleagues, in detecting a broader cleavage between what he terms " "environmental agnosticism" (a sceptical attitude towards evidence about environmental conditions)', which he associates mostly with European environmental sociologies and "environmental pragmatism" (an emphasis on measuring and investigating rather than problematizing such conditions)', which continues to characterise most North American contributions.

In setting out their original critique of the HEP, Catton and Dunlap $(1978,1980)$ made reference to Durkheim's declaration that social facts were reducible neither to biology nor psychology but could only be explained in reference to other social facts. Although Dunlap has since argued that their intention was simply to point out that over the course of the $20^{\text {th }}$ century Durkheim's dictum had become institutionalised within sociology, it nonetheless prompted a number of scholars, particularly in North America, to return to the discipline's classic texts and reveal their ecological underpinnings.

\section{Revisiting sociology's foundational works}

In their contribution to a symposium celebrating Catton and Dunlap's foundational work in establishing the NEP, Rosa and Richter (2008) challenged the idea that Durkheim should be 
seen as the original source of the HEP. They did this on three grounds. First, they questioned the pervasiveness of the notion that social facts are exclusively self-referential in the classical sociological canon. Second, they referred to Durkheim's 1893 work The Division of Labour in Society, pointing out his explicit recognition of the links between people, nature and society and that his model of social evolution resulting in the division of labour was driven by population growth and the attendant competition for natural resources. Finally, they examined Durkheim's 1887 inaugural lecture as the world's first professor of sociology, to elucidate precisely what Durkheim meant by the term 'social fact'. The key point of this lecture was to establish sociology as a science of social action. In doing so, Durkheim acknowledged the work of zoologists researching animal social behaviour, in establishing a basis for sociological method. More importantly, they claimed, his notion that societies are greater than the sum of their parts suggests the principle of 'emergence': a concept that resides at the heart of systems biology and is a key element of recent, critical realist proposals for an ecologically embedded sociology.

The possibility that Marx's thought might contribute useful concepts to an emergent ecological paradigm is far less problematic, as for him it was the continuous struggle to extract from nature the material means of social reproduction, which led to the discovery of increasingly advanced forces of production. Foster (2000) has provided significant new insight into the centrality of ecology to Marx's conception of the nature-society nexus, pointing out that Marx conceived of nature as our external or 'inorganic' body and claimed that, in order to flourish as human beings, we must maintain an intimate and on-going 'dialogue' with nature, a dialogue that is systematically denied by the alienating structures of capitalism. Our material exchanges with nature Marx characterised as 'socio-ecological metabolism' and he described the rupturing of this metabolic relationship that accompanied the development of capitalism in the $19^{\text {th }}$ century, as European populations migrated from the countryside to find industrial work in cities (Foster, 2000: 141-177).

Together with Hannah Holleman, Foster has also revisited the sociology of Max Weber (Foster \& Holleman, 2012). Weber dismissed the idea that we can know directly what he referred to as 'first nature', insisting that nature only becomes part of society through cultural representation (second nature). However, while there is a clear rejection of simple environmental determinism, Weber's sophisticated interpretive/causal-analytic position clearly acknowledges how the values and meanings attached to environmental conditions and events provide cause for social change, resulting in historically significant (socio-ecological) consequences. The most significant consequence of Weber's environmental analysis, suggest Foster and Holleman, is the extent to which it informed his critique of the 'origins, development and (perhaps) decline' of 'modern, rational-inorganic capitalism'. Weber's understanding of the impacts of agricultural industrialisation on the soil reflects Marx's notion of the 'metabolic rift', while his characterisation of capitalism as destroying everything that might restrict its progress, bears a clear resemblance to Schnaiberg's model of the 'treadmill of production'. Foster and Holleman conclude that Weber's 'refracted materiality' can assist in the task of bringing nature back in and 'constructing a sociology fully equipped to address the human-environmental challenges of the $21^{\text {st }}$ century' (2012: 1666-1667).

Table 2 summarises the environmental foundations of classical sociological thinking uncovered by recent scholarship. The final section of this chapter takes key elements from the preceding discussions and sets them within a critical realist ontology that might serve as an integrating framework for emerging ecosociologies. 


\begin{tabular}{|l|l|l|}
\hline $\begin{array}{l}\text { Durkheim } \\
\text { (Rosa \& Richter, 2008) }\end{array}$ & $\begin{array}{l}\text { Marx } \\
\text { (Foster, 2000) }\end{array}$ & $\begin{array}{l}\text { Weber } \\
\text { (Foster \& Holleman, 2012) }\end{array}$ \\
\hline $\begin{array}{l}\text { Social facts are not exclusively } \\
\text { self-referential. }\end{array}$ & $\begin{array}{l}\text { Nature as man's (sic) inorganic } \\
\text { body. }\end{array}$ & 'Refracted materiality' \\
\hline $\begin{array}{l}\text { Division of labour driven by } \\
\text { population growth and } \\
\text { competition for natural resources. }\end{array}$ & $\begin{array}{l}\text { To survive and thrive as human } \\
\text { beings, we must maintain a close } \\
\text { and continuing 'dialogue' with } \\
\text { nature. }\end{array}$ & $\begin{array}{l}\text { Values and meanings attached to } \\
\text { nature provide cause for social } \\
\text { change with historically } \\
\text { significant consequences. }\end{array}$ \\
\hline $\begin{array}{l}\text { That societies are greater than the } \\
\text { sum of their parts suggests the } \\
\text { principle of 'emergence'. }\end{array}$ & $\begin{array}{l}\text { Stoffwechsel socio-ecological } \\
\text { metabolism. }\end{array}$ & $\begin{array}{l}\text { Modern, rational-inorganic } \\
\text { capitalism. }\end{array}$ \\
\hline $\begin{array}{l}\text { 'Emergence' a key concept in } \\
\text { systems biology [and critical } \\
\text { realism]. }\end{array}$ & $\begin{array}{l}\text { Capitalist agriculture provokes } \\
\text { an irreparable rift in the } \\
\text { interdependent process of socio- } \\
\text { ecological metabolism'. }\end{array}$ & $\begin{array}{l}\text { Development limited by finite } \\
\text { nature of resources, especially } \\
\text { fossil fuels (coal/coke). }\end{array}$ \\
\hline
\end{tabular}

Table 2. The environment in the classical sociological canon.

\section{Towards an integrating framework for ecosociologies}

The preceding brief genealogy of sociological engagement with the material bases of social life reveals two broad epistemological approaches to incorporating nature into sociological analyses, either directly as biophysical explanatory variables or indirectly as culturally mediated social constructs. As Freudenberg et al. pointed out in 1995, most environmental sociology at the time maintained a clear distinction between the physical and the social dimensions of reality, such that even where analytic balance was attempted, the naturesociety dualism carried the inherent risk of analytic primacy being afforded to one or the other. In order to overcome this, Freudenberg and colleagues offered the notion of 'conjoint constitution', which highlights how 'what have commonly been taken to be "physical facts"... have been shaped... by social construction processes, while... what appear to be "strictly social" phenomena... have been shaped by the fact that social behaviors often respond to stimuli and constraints from the biophysical world' (Freudenberg et al., 1995: 366). The idea that society shapes nature and nature shapes society over time is encapsulated within the notion of 'coevolution' (Norgaard, 1994; Woodgate \& Redclift, 1998). Borrowing the term from evolutionary ecology, Norgaard suggests that human values, knowledge, institutions and technology all coevolve with the environment. As Manuel-Navarrete and Buzinde (2010) indicate, however, both conjoint constitution and coevolution are underlain by systemic or structuralist reasoning, which obscures 'agents' motivations and actual potential (e. g. introspective or reflexive power) to enact transformations or sustain reproductions, other than saying that these are determined culturally and historically' (Manuel-Navarrete \& Buzinde, 2010: 140). If addressing the global environmental crisis requires a radical transformation of the structures of modernity that created the crisis, Manuel-Navarrete and Buzinde ask, how can such a transformation occur, if human agency is so strongly conditioned by these same structures? Their answer is that the co-production of socioenvironmental structures must be 'mediated by a self-reflexive, or transcendental, form of agency enacted by individuals in their interaction with not only society and the environment, but also with themselves: with their inner worlds', what they term 'socioecological agency' (Manuel-Navarrete \& Buzinde, 2010: 140).

Conjoint constitution and coevolution are clearly helpful models for the study of naturesociety interaction, while socio-ecological agency provides the possibility of the material and social inventiveness required to imagine and create alternative socio-ecological realities. For Carolan (2005: 394-395), however, constructs such as conjoint constitution, coevolution and 
socio-ecological agency are problematic on a number of counts. To begin with, they do not explain the ontological asymmetry between nature and society - that without nature there can be no humans or human society. Carolan also claims that such concepts lack the capacity to speak of causal tendencies and objects that cannot be easily observed. He goes on to insist that because all socio-biophysical phenomena are seen as equally 'impure', the constructs lack the analytic power to distinguish between different types of hybridity. As a result, Carolan argues, the theoretical possibility of socio-ecologically reflexive agents developing ecological ethics to guide us out of our current environmental predicament is sacrificed. These criticisms are not, however, fatal. Carolan uses them to support his argument that before we can bring nature back in to sociological discourse and practice, we must first clarify what nature is.

Carolan proposes that nature be 'collapsed' into 'three open, embedded, and emergent strata': Nature, nature, and 'nature'. This, he claims, creates space for 'both dynamism and temporality to enter into our understanding of societal-biophysical interaction' and provides a 'pragmatic guide to more fully explore the diverse causal interactions that make up social life' (Carolan, 2005: 399). Nature (capitalised) refers to phenomena of materiality and physical causality that underlie the other two strata, while nature (lowercase) is 'the environment': the conjointly constituted, coevolving socio-biophysical world in which we participate. Finally, 'nature' (in inverted commas) is: 'the "nature" of discourse, power/knowledge, cultural violence, and discursive subjugation' (Carolan, 2005: 401). Table 3 sets out this ontological scheme and furnishes it with some of the concepts and theories already discussed, together with others that are briefly introduced in this section.

Nature, nature and 'nature' are porous strata: higher level phenomena (nature and 'nature') are rooted in and emerge from lower level phenomena. This proposition resonates with the Durkheimian notions that social facts are emergent properties and that the division of labour is driven by population growth and competition for resources. Causal tendencies do not reside in Nature alone, however. They are multidirectional: our discourses of 'nature' impact our material transactions within nature. Consequently, the stratified ontology also provides room for Weberian refracted materiality and the idea that cultural constructions ('nature') produce historically significant consequences. Thus the door is left open for methodological pluralism.

Marx's concept of socioecological metabolism is a phenomenon of nature (lowercase): an emergent property of the causal tendencies of Nature - the 'laws of thermodynamics' and the biochemical structure of metabolic pathways. At the same time, socioecological metabolism is shaped by human values, knowledge and organisation ('nature'), and technology (nature/artefacts), as suggested by the coevolutionary model of nature-society interaction. In her exploration of the origins of the concept of metabolism in the natural and social sciences, Fischer-Kowalski (1997: 119) describes social metabolism as 'the flow of materials and energy in ... society through the chain of extraction, production, consumption and disposal'. It is composed of endosomatic metabolism within the body to sustain physiological activity and exosomatic metabolism, outside the body, to enhance the productivity of labour through the development and operation of technology. She suggests that the 'study of the social (i. e. economic, technological and cultural) regulation of society's metabolism [should] become a genuine sociological task of highly practical value in view of the ecological problems' that confront us today. Fischer-Kowalski's proposal echoes Marx's claim that addressing the metabolic rift between town and country required the (ecologically) rational regulation of the metabolic relation between human beings and the earth (Foster, 2000). 
The concept of metabolic rift has been developed considerably since Foster brought it to the attention of the social sciences. In his (Forster, 2012) critique of EMT, he talks of a 'planetary rift' that goes well beyond the disruption of soil nutrient cycles, to encompass climate change, biodiversity depletion, desertification, declining water resources, chemical pollution and a host of other ecological issues, many of which 'are approaching points of irreversibility and cumulative, catastrophic change' (Forster, 2012: 211). From the critical realist position, while it may be possible to establish the validity of claims about material circumstances, their ultimate veracity remains unknowable and it is more important to understand where such claims originate, how they are sustained and contested, and how they serve particular political interests. What becomes apparent from such analyses is that some environmental claims are more powerful and violent than others, and that they support the interests of some social groups over those of others (Forsyth, 2003).

\begin{tabular}{|c|c|c|}
\hline $\begin{array}{l}\text { Real } \\
\text { objects and causal tendencies } \\
\text { existing in a state of } \\
\text { permanence-with flux }\end{array}$ & $\begin{array}{l}\text { Actual } \\
\text { environmental conditions and } \\
\text { flow of events in space-time } \\
\text { socio-biophysical } \\
\text { phenomena/hybrids }\end{array}$ & $\begin{array}{l}\text { Empirical } \\
\text { observations and social } \\
\text { constructions } \\
\text { refracted materiality }\end{array}$ \\
\hline \multirow[t]{3}{*}{ Nature } & $\begin{array}{l}\text { nature } \\
\text { (Weber's } 1^{\text {st }} \text { nature) }\end{array}$ & $\begin{array}{l}\text { 'nature' } \\
\text { (Weber's } 2^{\text {nd }} \text { nature) }\end{array}$ \\
\hline & emergence & \\
\hline & multi-directional causal tendences & \\
\hline $\begin{array}{l}\text { Unobserved/unobservable objects } \\
\text { and causal tendencies. } \\
\text { Thermodynamics } \\
\text { Gravity } \\
\text { Atmospheric physics. } \\
\text { Metabolic pathways. } \\
\text { Nutrient cycles: Carbon, Nitrogen, } \\
\text { Phosphorus, etc. } \\
\text { Ecological processes and causal } \\
\text { tendencies. }\end{array}$ & $\begin{array}{l}\text { Human populations: biologically } \\
\text { embodied and ecologically } \\
\text { embedded, socio-ecologically } \\
\text { structured. } \\
\text { Environmental social movements, } \\
\text { environmental states. } \\
\text { Cultural practice, direct } \\
\text { experience, socio-ecological } \\
\text { agency, cultural landscapes. } \\
\text { Artefacts, technology, industry. } \\
\text { Ecosystem/agroecosystems/ urban } \\
\text { ecosystems, biological diversity, } \\
\text { genomes. } \\
\text { Socio-ecological metabolism: } \\
\text { endosomatic and exosomatic flows } \\
\text { of energy and materials. } \\
\text { Carbon in lithosphere, hydrosphere } \\
\text { and biosphere. }\end{array}$ & $\begin{array}{l}\text { 'Global warming and climate } \\
\text { change' } \\
\text { 'Ecological modernisation, } \\
\text { sustainable consumption, } \\
\text { efficiency and sufficiency, } \\
\text { sustainable intensification, genetic } \\
\text { engineering, food security, carbon } \\
\text { capture and storage' } \\
\text { 'Knowledge rifts and epistemic } \\
\text { ruptures.' } \\
\text { 'Coevolution, conjoint } \\
\text { constitution, metabolic rifts, } \\
\text { ecological debt, ecological } \\
\text { footprints/ biocapacity, } \\
\text { environmental justice, post- } \\
\text { development discourses, food } \\
\text { sovereignty, degrowth.' }\end{array}$ \\
\hline
\end{tabular}

\section{Table 3. Reality as stratified, rooted and emergent}

In a very interesting and helpful contribution to contemporary discussions of the metabolic rift, Schneider and McMichael (2010), extend its social conceptualisation to include the practice as well as the organisation of labour and, in doing so, embed it more firmly in nature (lowercase). Their wider conceptualisation of the social dimensions of metabolism leads them to identify another rift: 'the capitalist division of labour creates a rift in the production and reproduction of embodied knowledge of local ecosystems and potentially sustainable... [labour] practices'. This 'knowledge rift', a rift between nature and 'nature', is compounded and deepened by what Schneider and McMichael term 'a further layer of violence' that of 
abstraction and scientific reductionism. 'Not only is the metabolic rift a material transformation of production, with spatial and ecological consequences, but also it involves an epistemological break... [it] conditions social thought' (Schneider \& McMichael, 2010: 477-478). In other words, the exosomatic metabolism of industrial capitalism threatens the basic endosomatic metabolism that sustains all life, while knowledge and epistemic rifts undermine human agency and society's ability to address the deepening metabolic rift.

The widening and deepening of the metabolic rift in ecological terms, has produced what is now widely referred to as 'ecological debt': the debt accumulated by the global North at the expense of the global South through the export of natural resources at prices that take no account of the degradation caused by their extraction, processing and distribution, nor the occupation of environmental space through the dumping of production wastes. In a recent article, Warleniusa et al. (2015) examine the relevance of ecological debt to the goal of environmental justice. Ecological debt implies biophysical measures, such as 'ecological footprint', legal instruments, such as those encompassed within multilateral environmental agreements; and the distributional principle that equality should be restored between those that over consume and pollute, and those that under consume and suffer from pollution. Thus, 'ecological debt' can be used to analyse environmental injustices within countries, between genders, classes, races and ethnic groups, as well as between nations, in order to inform and monitor the impact of policies aimed at restoring environmental justice and bringing global social metabolism back to a level at which a liveable nature (lowercase) can be sustained.

Schneider and McMichael (2010) argue that a reunification of the social and the ecological, in historical thought and practice, will be indispensable to repairing the metabolic rift, both conceptually and practically. The framework proposed by Carolan (2005) and similar efforts by York and Mancus (2008) and Forsyth (2003) towards critical human and political ecologies, are significant efforts in this direction. Establishing reality as an open, ontologically stratified whole, allows us to perceive the actual environments (natures) we experience, as spatially and temporally dynamic, coevolving flows of conjointly constituted socio-biophysical events, rooted in an underlying domain of real objects and causal tendencies existing in a state of permanence-with flux (Nature), but varyingly co-constructed and contested by different social groups. That is to say, the environment of human action is continually remade through socio-ecological agency.

Social facts may indeed reside in a distinct domain of reality ('nature'), but they are embedded in and emerge from lower level strata (Nature and nature) and are continually reproduced and refashioned through the intended and unintended consequences of the actions of socio-ecological agents. Thus, the 'reunification of the social and the ecological, in historical thought and practice' demanded by Schneider and McMichael must have its starting point within the individual, as a new form of socio-ecological agency characterised by reflexivity and an awareness of the interconnected character of individual, social and material forms of agency. The role of ecosociologies in the Anthropocene then becomes the analysis of alternative socio-ecological discourses and practices in terms of their capacity to heal the planetary metabolic rift, address the intra- and inter-generational dimensions of ecological debt and promote environmental justice. 


\section{References}

BuTTEL Frederick H. (1987), 'New Directions in Environmental Sociology', Annual Review of Sociology, 13: 465-488.

CAROLAN Michael S. (2005), 'Society, Biology, and Ecology: Bringing Nature Back into Sociology's Disciplinary Narrative Through Critical Realism', Organization \& Environment, 18 (4): 393-421.

CATton William R. Jr., Dunlap Riley E. (1978), 'Environmental Sociology: A New Paradigm', The American Sociologist, 13: 41-49.

Catton William R. Jr., Dunlap Riley E. (1980), 'A New Ecological Paradigm for PostExuberant Sociology', American Behavioral Scientist, 25: 15-47.

DIETZ Thomas, RosA Eugene A. (1994), 'Rethinking the Environmental Impacts of Population, Affluence and Technology', Human Ecology Review, 1: 277-300.

DunlaP Riley E. (2010), 'The Maturation and Diversification of Environmental Sociology: from Constructivism and Realism to Agnosticism and Pragmatism', in: Redclift Michael and Woodgate Graham (eds.), The International Handbook of Environmental Sociology $2^{\text {nd }}$ Edition, Cheltenham, UK and Northampton, MA: Edward Elgar: 15-32.

Dunlap Riley E., VAn Liere Kent D., Mertig Angela G. and Jones Robert E. (2000), 'Measuring endorsement of the new ecological paradigm: a revised NEP scale', Journal of Social Issues, 56 (3): 425-42.

FiSCHER-KowALSKI, Marina (1997), 'Society's metabolism', in: Redclift Michael, Woodgate Graham (eds.), The International Handbook of Environmental Sociology, Cheltenham, UK, Northampton, MA: Edward Elgar: 119-137.

FORSYTH Tim (2003), Critical Political Ecology, London, Routledge.

Foster (2000), Marx's Ecology: Materialism and Nature, New York, Monthly Review Press.

FosteR, John B. (2012) 'The Planetary Rift and the New Human Exemptionalism', Organization \& Environment, 25 (3): 211-237.

Foster John B., Holleman Hannah (2012), 'Weber and the environment: Classical foundations for a postexemptionalist sociology', American Journal of Sociology, 117: $1625-1673$.

Freudenburg William R, Frickel Scott, Gramling Robert (1995), 'Beyond the nature/society divide: learning to think about a mountain', Sociological Forum, 10: 361-392.

HANNIGAN John (2014; $3^{\text {rd }}$ ed.), Environmental Sociology, London, Routledge.

HUBER Joseph (2000), 'Towards industrial ecology: sustainable development as a concept of ecological modernization', Journal of Environmental Policy and Planning, 2 (4): 269-285.

LIDSKOG Rolf, MOL Arthur, OOSTERVEER Peter (2015), 'Towards a global environmental sociology? Legacies, trends and future directions', Current Sociology, 63 (3): 339368.

MACNAGHTEN Philip, URRY John (1995), 'Towards a Sociology of Nature', Sociology, 29 (2): 203-220.

Manuel Navarrete David, BuZinde Christine N. (2010), 'Socio-ecological Agency: from "human exceptionalism" to coping with exceptional environmental change' in: Redclift Michael, Woodgate Graham (eds.), The International Handbook of Environmental Sociology $2^{\text {nd }}$ Edition, Cheltenham, UK, Northampton, MA: Edward Elgar: 136-149. 
MCCRIGHT Aaron, DunlaP Riley (2010), 'Anti-reflexivity: The American Conservative Movement's Success in Undermining Climate Science and Policy', Theory, Culture \& Society, 27 (2-3): 100-33.

Mol Arthur P.J. (1997), 'Ecological modernization: industrial transformations and environmental reform', in: Redclift Michael, Woodgate Graham (eds.), The International Handbook of Environmental Sociology, Cheltenham, UK, Northampton, MA: Edward Elgar: 138-149.

Mol Arthur P. J., BuTTEL Frederick H. (eds.) (2002), The Environmental State Under Pressure, Oxford, Elsevier: 149-169.

NORGAARD Richard B. (1994), Development Betrayed: The End of Progress and a Coevolutionary Revisioning of the Future, London, New York, Routledge.

REDCLIFT Michael, WoOdGATE Graham (2014), 'The European Contribution to Environmental Sociology', in: Koniordos Sokratis, Kyrtsis Alexandros-Andreas, (eds.), Routledge Handbook of European Sociology, Oxford, UK, New York, Routledge: 225-237.

RosA Eugene A., RICHTER Lauren (2008), 'Durkheim on the Environment: Ex Libris or Ex Cathedra? Introduction to Inaugural Lecture to a Course in Social Science, 18871888', Organization \& Environment, 21 (2): 182-187.

SCHNAIBERG Allan (1975), 'Social syntheses of the societal environmental dialectic: the role of distributional impacts', Social Science Quarterly, 56: 5-20.

SCHNAIBERG Allan (1980), The Environment: from Surplus to Scarcity, New York, Oxford University Press.

SCHNEIDER Mindi, MCMichael Philip (2010), 'Deepening, and repairing, the metabolic rift', Journal of Peasant Studies, 37 (3): 461-484.

SHACKLEY Simon, WyNNE Brian (1996), 'Representing uncertainty in global climate change and policy', Science, Technology and Human Values, 21: 275-302.

WARLENIUSA Rikard, PIERCEA Gregory, RAMASARB Vasna (2015), 'Reversing the arrow of arrears: The concept of "ecological debt" and its value for environmental justice', Global Environmental Change, 30: 21-30.

WOODGATE Graham, REDCLIFT Michael (1998), 'From a "sociology of nature" to environmental sociology: beyond social construction', Environmental Values, 7: 324.

Wynne Brian (2010), 'Strange Weather, Again: Climate Science as Political Art', Theory, Culture \& Society, 27 (2-3): 289-305.

YORK Richard, Rosa Eugene A., DIETZ Thomas (2003), 'Footprints on the earth: the environmental consequences of modernity', American Sociological Review, 68: 279300.

YORK Richard, MANCUS Philip (2009), 'Critical Human Ecology: Historical Materialism and Natural Laws', Sociological Theory, 27 (2): 122-149.

\footnotetext{
${ }^{1}$ There is not room here for a full account of these developments and so readers are also referred to the some of the many assessments of environmental sociology's recent genealogy. See, inter alia: Buttel (1987); Dunlap (2010); Hannigan (2014: 18-49); Lidskog et al. (2015); Redclift and Woodgate (2014).

${ }^{2}$ Impact $=$ Population $\mathrm{x}$ Affluence $\mathrm{x}$ Technology.

${ }^{3}$ STochastic Impacts by Regression on Population, Affluence and Technology.

${ }^{4}$ It is also important to note significant contributions to environmental sociology from scholars outside Europe and North America, in countries such as China, Japan, South Korea, Argentina, Brazil, and Chile. See Lidskog et al. (2015) and Dunlap (2010).

${ }^{5}$ This debate has been reviewed by scholars from both camps (see, inter alia, Dunlap 2010; Lidskog et al. 2015).
} 